\title{
RELATIONSHIP BETWEEN INSULIN-LIKE GROWTH FACTOR TYPE 1 AND INTRAUTERINE GROWTH
}

\author{
Lidija Banjac ${ }^{1}$, Jelena Kotur-Stevuljević2 ,Tamara Gojković², Vesna Bokan-Mirković3 \\ Goran Banjac ${ }^{4}$ and Gorica Banjac ${ }^{5}$
}

\author{
${ }^{1}$ Department of Neonatology, Clinical Center of Montenegro, Podgorica, Montenegro; \\ ${ }^{2}$ Institute of Medical Biochemistry, Faculty of Pharmacy, University of Belgrade, Belgrade, Serbia; \\ ${ }^{3}$ Center for Physical Medicine and Rehabilitation, Clinical Center of Montenegro, Podgorica, Montenegro; \\ ${ }^{4}$ Institute of Children's Diseases, Clinical Center of Montenegro, Podgorica, Montenegro; \\ ${ }^{5}$ The Obstetrics and Gynaecology Clinic Narodni Front, Belgrade, Serbia
}

\begin{abstract}
SUMMARY - Insulin-like growth factor 1 (IGF-1) is a regulator of intrauterine growth, and circulating concentrations are reduced in intrauterine growth-restricted fetuses. The aim of our study was to investigate the relationship between IGF-1 levels in newborns and intrauterine growth, expressed as birth weight (BW). The research was designed as a cross-sectional study. The study included 71 premature newborns, gestational age (GA) $\leq 33$ weeks. Quantitative determination of IGF-1 was performed in the $33^{\text {rd }}$ post-menstrual week (pmw) to make the measurements more comparable. We used an enzyme-bound immunosorbent test for quantitative determination of IGF1. Our results showed the mean IGF-1 level in premature newborns in $33^{\text {rd }}$ pmw to be $23.1 \pm 4.56$ (range 15.44-39.75) $\mu \mathrm{g} / \mathrm{L}$. There was no difference in IGF-1 values between male $(23.1 \pm 4.98 \mu \mathrm{g} / \mathrm{L})$ and female $(23.1 \pm 4.87 \mu \mathrm{g} / \mathrm{L})$ newborns. There was no significant difference in the average IGF-1 levels between male and female newborns with $\mathrm{BW}<50^{\text {th }}$ and $\mathrm{BW}>50^{\text {th }}$ percentile for $\mathrm{GA}$ either $(\mathrm{p}>0.50)$. Only BW $<33^{\text {rd }}$ percentile newborns had a statistically significantly lower IGF- 1 level compared to newborns with greater BW. Based on our results, it is concluded that serum IGF-1 level reflects intrauterine growth only in BW $<33^{\text {rd }}$ percentile newborns. This fact could be used for further therapeutic purposes.

Key words: Infant, newborn; Insulin-like growth factor I; Fetal growth retardation; Cross-sectional studies
\end{abstract}

\section{Introduction}

Intrauterine growth restriction (IUGR) is usually the end result of maternal, placental, fetal and genetic causes. Endocrine environment controls the growth of the fetus and endocrine causes are responsible for IUGR development ${ }^{1}$. Multiple hormonal interactions are able to produce a specific pattern of intrauterine development with potential lifelong consequences for health ${ }^{2}$. Fetal endocrine system also plays a significant

Correspondence to: Lidija Banjac, U1. Đoka Mirašević M1 53/7, Podgorica, Montenegro

E-mail: drbanjac@t-com.me

Received December 5, 2018, accepted November 11, 2019 role in helping the fetus adjust to extrauterine environment ${ }^{1,3}$.

Insulin-like growth factor 1 (IGF-1) is a polypeptide hormone produced mainly by the liver in response to the endocrine growth hormone stimulus, but it is also secreted by multiple tissues for autocrine/paracrine purposes. During fetal life, IGF-1 is mostly secreted in the placenta ${ }^{4}$. IGF- 1 possesses a wide number of own activities such as anabolic, antioxidant, anti-inflammatory and cytoprotective actions ${ }^{5}$. Many authors have investigated the relationship between IGF-1 and diseases of prematurity ${ }^{6,7}$ IGF-1 is an important regulator of fetal growth, and circulating concentrations are reduced in intrauterine growth-re- 
stricted fetuses ${ }^{8}$. The latest studies have shown positive correlation between birth weight (BW), gestational age (GA) and umbilical cord serum IGF-1 levels ${ }^{9,10}$. Also, these studies have shown that in humans, IUGR is correlated to high levels of serum IGF binding protein-1 (IGFBP-1) ${ }^{4}$. The IGF/IGFBP system is involved in fetal growth, bone mineralization, and energetic status in humans ${ }^{10,11}$. The IGFs are necessary for normal brain development and function, and may affect brain growth and neurologic development ${ }^{12}$.

The list of roles of IGF- 1 is increased, both in physiological and pathological conditions, underlying that its potential therapeutic options seem to be limited to those proven states of local or systemic IGF-1 deficiency as a replacement treatment, rather than increasing its upper normal range 5 .

The aim of the study was to investigate the relationship between IGF-1 levels in newborns and intrauterine growth expressed as BW, and secondly to determine whether there was a difference in IGF-1 levels between male and female newborns.

\section{Materials and Methods}

This study was performed at Department of Neonatology, Clinical Center of Montenegro, Podgorica, after approval from the institutional Ethics Committee (consent number 03/01-3813/4). The mothers signed an informed consent to participate in the study. The study was designed as a cross-sectional study. The study included 71 premature newborns, GA $\leq 33$ weeks, hospitalized at Department of Neonatology, Clinical Center of Montenegro. Newborns with conspicuous congenital anomalies were not included in the study.

A database was formed including demographic data, data from pregnancy and delivery (GA) and anthropometric measures at birth (BW). In every newborn included in the study, venous blood sample (0.5 $\mathrm{mL}$ ) was obtained in $33^{\text {rd }}$ postmenstrual week (pmw) to make the measurements more reliable and comparable. The samples (serum) were frozen and stored in a freezer $\left(-80^{\circ} \mathrm{C}\right)$ until completion of a series of samples. In all samples, quantitative determination of the requested biomarker (IGF-1) was performed simultaneously, under the same conditions, using immunochemical enzyme-linked immunosorbent as- say (ELISA), a method widely used on this hormone measurement ${ }^{13}$.

For percentile average BW of male/female infants, we used the RCPCH UK-WHO Neonatal and Infant Close Monitoring Growth Chart 2009 ${ }^{14,15}$. Based on these growth charts, male and female newborns were divided into two subgroups of newborns with BW below the $50^{\text {th }}$ percentile $\left(\mathrm{BW}<50^{\text {th }}\right)$ for GA and newborns with $\mathrm{BW}$ above the $50^{\text {th }}$ percentile $\left(\mathrm{BW}>50^{\text {th }}\right)$ for GA. We compared the mean levels of IGF-1 between the groups.

In the second step, we determined the $33^{\text {rd }}$ percentile $(1481 \mathrm{~g})$ of BW for the whole group of newborns and obtained two groups of BW below the $33^{\text {rd }}$ percentile $\left(\mathrm{BW}<33^{\text {rd }}\right)$ and $\mathrm{BW}$ above the $33^{\text {rd }}$ percentile $\left(\mathrm{BW}>33^{\mathrm{rd}}\right)$. We compared the levels of IGF-1 between the groups.

Statistical data processing included calculation of descriptive measures, use of statistical tests and statistical software programs (IBM, SPSS) for comparisons of parameters between the subgroups. Normality of data was tested by Kolmogorov-Smirnov test. The following statistical tests were used: Student's t-test, ANOVA test, Kruskal-Wallis test with distinct posthoc tests (Tukey test for parametric ANOVA and Mann-Whitney U test for Kruskal-Wallis non-parametric test). Univariate associations were evaluated using Pearson's correlation analysis. In all tests used, the level of statistical significance was set at $\mathrm{p}<0.05$.

\section{Results}

There were $42(59.15 \%)$ male and $29(40.85 \%)$ female newborns. The mean BW of newborns in primary cohort was $1708.4 \pm 403.64$ (range 990-2860) g, mean GA 31.2 \pm 1.87 (range 26-33) gestational weeks, and mean IGF-1 level 23.1 \pm 4.56 (range 15.44-39.75) $\mathrm{mcg} / \mathrm{L}$. Average BW (in grams) and percentiles of BW in groups with the same GA are shown in Tables 1 and 2. Table 3 shows BW, GA and IGF-1 levels of male and female newborns. Student's t-test revealed difference in BW, GA and IGF-1 level. Male newborns had a significantly higher BW, but there was no sex difference in GA. There was no difference in the levels of IGF- 1 between male $(23.2 \pm 4.98 \mathrm{mcg} / \mathrm{L})$ and female $(23.1 \pm 4.87 \mathrm{mcg} / \mathrm{L})$ newborns $(\mathrm{p}>0.05 ; \mathrm{t}=1.284)$.

To further explore the relationship of $\mathrm{BW}$ and IGF-1, we divided each group of participants (male and 
Table 1. Average percentiles of birth weight (BW, grams) in male newborns ( $N=42)$ in groups of the same gestational age $(G A)$

\begin{tabular}{|l|l|l|l|l|l|l|l|l|l|l|l|}
\hline \multirow{2}{*}{ GA (weeks) } & \multicolumn{2}{|c|}{$<10^{\text {th }}$ percentile } & \multicolumn{2}{|c|}{$<31^{\text {st }}$ percentile } & \multicolumn{2}{c|}{$<50^{\text {th }}$ percentile } & \multicolumn{2}{|c|}{$<66^{\text {th }}$ percentile } & \multicolumn{2}{|c|}{$<90^{\text {th }}$ percentile } \\
\cline { 2 - 10 } & BW $(\mathrm{g})$ & $\mathrm{n}$ & $\mathrm{BW}(\mathrm{g})$ & $\mathrm{n}$ & $\mathrm{BW}(\mathrm{g})$ & $\mathrm{n}$ & $\mathrm{BW}(\mathrm{g})$ & $\mathrm{n}$ & $\mathrm{BW}(\mathrm{g})$ & $\mathrm{n}$ \\
\hline$\leq 28$ & $<890$ & & $<1080$ & 1 & $<1150$ & 1 & $<1200$ & 1 & $<1400$ & 1 \\
29 & $<1000$ & & $<1150$ & & $<1290$ & & $<1350$ & 1 & $<1590$ & 1 \\
30 & $<1110$ & & $<1350$ & 1 & $<1425$ & & $<1500$ & 1 & $<1800$ & 3 \\
31 & $<1210$ & & $<1500$ & 2 & $<1600$ & & $<1700$ & 2 & $<2000$ & 1 \\
32 & $<1370$ & & $<1700$ & 2 & $<1800$ & 3 & $<1900$ & 2 & $<2200$ & 6 \\
33 & $<1570$ & & $<1880$ & 5 & $<2000$ & 3 & $<2120$ & 2 & $<2500$ & $2+1^{*}$ \\
\hline
\end{tabular}

*one newborn with $\mathrm{BW}>90^{\text {th }}$ percentile $(\mathrm{BW}=2860 \mathrm{~g})$

Source: average BW of male infants (RCPCH UK-WHO Neonatal and Infant Close Monitoring Growth Chart 2009 ${ }^{14}$ ).

Table 2. Average percentiles of birth weight (BW, grams) in female newborns $(N=29)$ in groups of the same gestational age $(G A)$

\begin{tabular}{|l|l|l|l|l|l|l|l|l|l|l|l|l|}
\hline \multirow{2}{*}{ GA (weeks) } & \multicolumn{2}{|l|}{$<10^{\text {th }}$ percentile } & \multicolumn{2}{|c|}{$<31^{\text {st }}$ percentile } & \multicolumn{2}{c|}{$<0^{\text {th }}$ percentile } & \multicolumn{2}{|c|}{$<6^{\text {th }}$ percentile } & \multicolumn{2}{|c|}{$<90^{\text {th }}$ percentile } \\
\cline { 2 - 10 } & BW $(\mathrm{g})$ & $\mathrm{n}$ & $\mathrm{BW}(\mathrm{g})$ & $\mathrm{n}$ & $\mathrm{BW}(\mathrm{g})$ & $\mathrm{n}$ & $\mathrm{BW}(\mathrm{g})$ & $\mathrm{n}$ & $\mathrm{BW}(\mathrm{g})$ & $\mathrm{n}$ \\
\hline$\leq 28$ & $<810$ & & $<1040$ & & $<1190$ & 1 & $<1150$ & 1 & $<1350$ & 5 \\
29 & $<900$ & & $<1120$ & 1 & $<1200$ & 1 & $<1300$ & & $<1500$ & \\
30 & $<1010$ & & $<1260$ & & $<1350$ & & $<1450$ & 1 & $<1700$ & 1 \\
31 & $<1130$ & & $<1320$ & 1 & $<1510$ & 1 & $<1610$ & 1 & $<1900$ & 4 \\
32 & $<1300$ & & $<1600$ & 2 & $<1700$ & & $<1810$ & 1 & $<2110$ & \\
33 & $<1450$ & 1 & $<1690$ & 1 & $<1900$ & 1 & $<1930$ & & $<2600$ & 5 \\
\hline
\end{tabular}

Source: average BW of female infants (RCPCH UK-WHO Neonatal and Infant Close Monitoring Growth Chart 2009 ${ }^{15}$ ).

female) into two subgroups of newborns with $\mathrm{BW}<50^{\text {th }}$ percentile and newborns with $\mathrm{BW}>50^{\text {th }}$ percentile.

There were 18 male newborns with $\mathrm{BW}<50^{\text {th }}$ percentile and their mean BW was $1588.3 \pm 244.06 \mathrm{~g}$. There were 24 male newborns with $\mathrm{BW}>50^{\text {th }}$ percentile and their mean BW was $1951.7 \pm 444.70 \mathrm{~g}$.

There were 10 female newborns with $\mathrm{BW}<50^{\text {th }}$ percentile and their mean BW was $1446 \pm 295.57 \mathrm{~g}$. There were 19 female newborns with $\mathrm{BW}>50^{\text {th }}$ percentile and their mean BW was $1653.2 \pm 382.33 \mathrm{~g}$.

Gestational age and serum levels of IGF-1 are shown in Tables 4 and 5 . The subgroups of male infants did not differ according to GA ( $p>0.05 ; \mathrm{t}=1.801)$ and there was no significant difference in the levels of IGF-1 ( $p>0.05 ; t=2.064)$ either. The subgroups of female newborns did not differ according to $G A$ ( $p>0.05$; $\mathrm{t}=1.745)$ and there was no significant difference in the levels of IGF-1 ( $p>0.05 ; \mathrm{t}=2.758)$.

In the next step, the male and female groups were divided into two subgroups according to the cut-off
Table 3. Birth weight (BW), gestational age (GA) and levels of insulin-like growth factor-1 (IGF-1) according to gender

\begin{tabular}{|c|c|c|c|}
\hline Parameter & Male, $\mathrm{N}=42$ & Female, $N=29$ & $\begin{array}{l}\mathrm{p} \text { and } \mathrm{t} \\
\text { values** }\end{array}$ \\
\hline BW $(g)^{*}$ & $1796.0 \pm 410.80$ & $1581.7 \pm 363.45$ & $\begin{array}{l}\mathrm{p}<0.05 ; \\
\mathrm{t}=2.022\end{array}$ \\
\hline $\begin{array}{l}\text { GA } \\
\text { (weeks)* }\end{array}$ & $31.4 \pm 1.74$ & $30.8 \pm 2.02$ & $\begin{array}{l}p>0.05 ; \\
t=1.321\end{array}$ \\
\hline $\begin{array}{l}\text { IGF-1 } \\
(\mathrm{mcg} / \mathrm{L})^{*}\end{array}$ & $23.2 \pm 4.98$ & $23.1 \pm 4.87$ & $\begin{array}{l}p>0.05 ; \\
t=1.284\end{array}$ \\
\hline
\end{tabular}

*values expressed as mean $\pm \mathrm{SD}$; **Student's t-test

$33^{\text {rd }}$ percentile (1481 g) of BW and compared according to IGF-1 levels (Tables 6 and 7).

Tables 6 and 7 show the values of GA and IGF-1 in male and female newborns below $\left(B W<33^{\text {rd }}\right)$ and above $\left(\mathrm{BW}>33^{\text {rd }}\right)$ the $33^{\text {rd }}$ percentile of $\mathrm{BW}$. There 
Table 4. Gestational age (GA) and levels of insulin-like growth factor-1 $(I G F-1)$ in male newborns $(N=42)$ with birth weight $(B W)>50^{\text {th }}$ percentile and $B W$ $<50^{\text {th }}$ percentile

\begin{tabular}{|c|c|c|c|}
\hline Parameter & $\begin{array}{l}\mathrm{BW}>50^{\text {th }} \\
\text { percentile } \\
\mathrm{n}=24\end{array}$ & $\begin{array}{l}\mathrm{BW}<50^{\text {th }} \\
\text { percentile } \\
\mathrm{n}=18\end{array}$ & $\begin{array}{l}\mathrm{p} \text { and } \mathrm{t} \\
\text { values }\end{array}$ \\
\hline $\begin{array}{l}\text { GA } \\
(\text { weeks) }\end{array}$ & $31.2 \pm 1.89$ & $31.6 \pm 1.54$ & $\begin{array}{l}p>0.05 \\
t=1.801\end{array}$ \\
\hline $\begin{array}{l}\mathrm{IGF}-1 \\
(\mathrm{mcg} / \mathrm{L})^{*}\end{array}$ & $23.6 \pm 5.31$ & $22.6 \pm 4.60$ & $\begin{array}{l}p>0.05 \\
t=2.064\end{array}$ \\
\hline
\end{tabular}

values expressed as mean $\pm \mathrm{SD}$; "Student's t-test

Table 5. Gestational age (GA) and levels of insulin-like growth factor-1 $(I G F-1)$ in female newborns $(N=29)$ with birth weight $(B W)>50^{\text {th }}$ percentile and $B W$ $<50^{\text {th }}$ percentile

\begin{tabular}{|c|c|c|c|}
\hline Parameter & $\begin{array}{l}\mathrm{BW}>50^{\text {th }} \\
\text { percentile } \\
\mathrm{n}=19\end{array}$ & $\begin{array}{l}\mathrm{BW}<50^{\text {th }} \\
\text { percentile } \\
\mathrm{n}=10\end{array}$ & $\begin{array}{l}p \text { and } t \\
\text { values }\end{array}$ \\
\hline $\begin{array}{l}\text { GA } \\
\text { (weeks) }\end{array}$ & $30.5 \pm 2.09$ & $31.5 \pm 1.78$ & $\begin{array}{l}p>0.05 ; \\
t=1.745\end{array}$ \\
\hline $\begin{array}{l}\text { IGF-1 } \\
(\mathrm{mcg} / \mathrm{L})^{*}\end{array}$ & $23.2 \pm 2.09$ & $22.8 \pm 3.46$ & $\begin{array}{l}p>0.05 \\
t=2.758\end{array}$ \\
\hline
\end{tabular}

values expressed as mean $\pm \mathrm{SD}$; "Student's t-test

were 24 newborns with $\mathrm{BW}<33^{\text {rd }}$ and 47 with $\mathrm{BW}$ $>33^{\text {rd }}$ percentile.

There were 11 male newborns with $\mathrm{BW}<33^{\text {rd }}$ percentile $(1301.8 \pm 157.09 \mathrm{~g})$ and 31 male newborns with BW $>33^{\text {rd }}$ percentile $(1971.3 \pm 317.98 \mathrm{~g})$. There were 13 female newborns with BW $<33^{\text {rd }}$ percentile $(1253.1 \pm$ $127.63 \mathrm{~g}$ ) and 16 female newborns with $\mathrm{BW}>33^{\text {rd }}$ percentile $(1848.8 \pm 252.74 \mathrm{~g})$.

Data analysis yielded a statistically significant difference in IGF-1 levels between the groups. The newborns (male and female) with $\mathrm{BW}<33^{\text {rd }}$ percentile had a statistically significantly lower level of IGF-1 than the respective newborns with higher BW (male $\mathrm{p}<0.05, \mathrm{U}=14$ and female $\mathrm{p}<0.05, \mathrm{U}=49$ ).

\section{Discussion and Conclusion}

Intrauterine growth is a complex process involving maternal, placental and fetal factors of genetic, environmental and nutritional nature. BW has served as a
Table 6. Gestational age (GA) and levels of insulin-like growth factor-1 (IGF-1) in male newborns according to birth weight $(B W)$ cut-off value of $1481 \mathrm{~g}$

( $33^{\text {rd }}$ percentile for the whole group)

\begin{tabular}{|l|l|l|l|}
\hline Parameter & $\begin{array}{l}\mathrm{BW}>33^{\text {rd }} \\
\text { percentile } \\
\mathrm{n}=31\end{array}$ & $\begin{array}{l}\mathrm{BW}<33^{\text {rd }} \\
\text { percentile } \\
\mathrm{n}=11\end{array}$ & $\begin{array}{l}\mathrm{p} \text { and } \mathrm{t} / \mathrm{U} \\
\text { values }\end{array}$ \\
\hline $\begin{array}{l}\text { GA } \\
(\text { weeks) }\end{array}$ & $32.1 \pm 0.96$ & $29.3 \pm 1.74$ & $\begin{array}{l}\mathrm{p}<0.001^{\mathrm{a}} ; \\
\mathrm{t}=3.251^{\mathrm{a}^{*}}\end{array}$ \\
$\begin{array}{l}\text { IGF-1 } \\
(\mathrm{mcg} / \mathrm{L})^{*}\end{array}$ & $\begin{array}{l}22.3 \\
(21.09-25.60)\end{array}$ & $\begin{array}{l}18.7 \\
(18.02-23.31)\end{array}$ & $\begin{array}{l}\mathrm{p}<0.05^{\mathrm{a}} ; \\
\mathrm{U}=14^{* *}\end{array}$ \\
\hline
\end{tabular}

Data expressed as mean $\pm \mathrm{SD}$; IGF expressed as median $\left(25^{\text {th }}-75^{\text {th }}\right.$ percentile) because of data non-normality; BW $33^{\text {rd }}$ percentile $=$ 1481 g; "Student's t-test; "Mann-Whitney U test; a = male BW $<33^{\text {rd }} v s$. male $\mathrm{BW}>33^{\text {rd }}$

Table 7. Gestational age $(G A)$ and levels of insulin-like growth factor-1 (IGF-1) in female newborns $(N=29)$ according to birth weight (BW) cut-off value of $1481 \mathrm{~g}$ (33 $3^{\text {rd }}$ percentile for the whole group)

\begin{tabular}{|l|l|l|l|}
\hline Parameter & $\begin{array}{l}\mathrm{BW}>33^{\text {rd }} \\
\text { percentile } \\
\mathrm{n}=16\end{array}$ & $\begin{array}{l}\mathrm{BW}<33^{\text {rd }} \\
\text { percentile } \\
\mathrm{n}=13\end{array}$ & $\begin{array}{l}\mathrm{p} \text { and } \mathrm{t} / \mathrm{U} \\
\text { values }\end{array}$ \\
\hline $\begin{array}{l}\text { GA } \\
(\text { weeks) }\end{array}$ & $32.1 \pm 1.06$ & $29.3 \pm 1.89$ & $\begin{array}{l}\mathrm{p}<0.001^{\mathrm{b}} ; \\
\mathrm{t}=2.257^{\mathrm{b}^{*}}\end{array}$ \\
$\begin{array}{l}\text { IGF-1 } \\
(\mathrm{mcg} / \mathrm{L})^{*}\end{array}$ & $\begin{array}{l}22.4 \\
(20.31-26.81)\end{array}$ & $\begin{array}{l}21.2 \\
(19.59-23.17)\end{array}$ & $\begin{array}{l}\mathrm{U}=0.05^{\mathrm{b}} ; \\
\mathrm{U}=49^{* *}\end{array}$ \\
\hline
\end{tabular}

Data expressed as mean $\pm \mathrm{SD}$; TGF expressed as median $\left(25^{\text {th }}-75^{\text {th }}\right.$ percentile) because of data non-normality; BW $33^{\text {rd }}$ percentile = 1481 g; "Student's t-test; "Mann-Whitney U test; b = female BW $<33^{\text {rd }} v$ s. female $\mathrm{BW}>33^{\text {rd }}$

surrogate marker of fetal growth, nutrition and health. In this study, we used BW as a marker of fetal growth.

A growth-restricted fetus/newborn is characterized by an increased rate of fetal and neonatal mortality and morbidity and an increased risk of chronic adult diseases such as neurodevelopmental outcome, cardiovascular disease, diabetes and obesity ${ }^{16-18}$.

Many authors have clearly established that IGF-1 is the main regulator of intrauterine growth, as confirmed by correlation between low BW and low cord serum IGF-111,19. However, some studies failed to show any association between intrauterine growth and IGF-17,20. Discrepancies in previous studies could partly be explained by difficulties in obtaining reliable measurements, common problems when studying newborns, especially preterms ${ }^{19}$. 
In our study, we obtained blood samples at $33^{\text {rd }}$ pmw uniformly to reduce the possibility of error and to ensure better comparison of the results.

Our results showed that there was no significant difference in IGF-1 level between male and female newborns. Other authors report that female newborns have higher IGF-1 levels than males, explaining it by the size at birth being a composite of factors determined by gender ${ }^{21}$. Also, the IGF-1 levels in umbilical cord plasma were higher in female newborns, but contributed positively to BW in both sexes ${ }^{22}$.

Our results showed that there was no statistically significant difference in IGF-1 levels between the newborns with $\mathrm{BW}<50^{\text {th }}$ percentile and newborns with $\mathrm{BW}>50^{\text {th }}$ percentile. The newborns (male and female) with $\mathrm{BW}<50^{\text {th }}$ percentile had lower IGF-1 level than newborns with $\mathrm{BW}>50^{\text {th }}$ percentile, but this difference was not statistically significant.

In the next step, the primary cohort was divided into two groups according to the cut-off $33^{\text {rd }}$ percentile (BW $1481 \mathrm{~g}$ ). We found a statistically significant between-group difference according to IGF-1 levels. Newborns with $\mathrm{BW}<33^{\text {rd }}$ percentile had a significantly lower IGF-1 level than newborns with higher BW. Other authors have reported similar results, indicating that IGF-1 reflects concurrent short-term growth velocity in $\mathrm{BW}>33^{\text {rd }}$ percentile newborns ${ }^{22.23}$.

Our results showed that there was no statistically significant difference in IGF-1 levels according to gender. IGF-1 levels of newborns below and above the $50^{\text {th }}$ percentile of BW according to GA showed no difference either. Only BW $<33^{\text {rd }}$ percentile newborns had a statistically significantly lower level of IGF-1. Based on our results, it is concluded that serum IGF-1 levels reflect intrauterine growth only in $\mathrm{BW}<33^{\text {rd }}$ percentile newborns.

According to our results, similar levels of IGF-1 in both male and female newborns facilitate interpretation of results and suggest uniform protocols (in both genders) for the use of IGF-1 in the treatment of IUGR.

\section{Acknowledgment}

This work was supported by grant from the Ministry of Education and Science, Republic of Serbia (Project No. 175035).

\section{References}

1. Sharma D, Sharma P, Shastri S. Genetic, metabolic and endocrine aspects of intrauterine growth restriction: an update. J Matern Fetal Neonatal Med. 2017;30(19):2263-75. https:// doi.org/10.1080/14767058.2016.1245285

2. Sferruzzi-Perri AN, Vaughan OR, Forhead AJ, Fowden AL. Hormonal and nutritional drivers of intrauterine growth. Curr Opin Clin Nutr Metab Care. 2013;16(3):298-309. http:// doi: 10.1097/mco.0b013e32835e3643

3. Kota SK, Gayatri K, Jammula S, Meher LK, Kota SK, Krishna $\mathrm{SV}$, et al. Fetal endocrinology. Indian J Endocrinol Metab. 2013;17(4):568-79. http://doi: 10.4103/2230-8210.113722

4. Singal SS, Nygard K, Gratton R, Jansson T, Gupta MB. Increased insulin-like growth factor binding protein-1 phosphorylation in decidualized stromal mesenchymal cells in human intrauterine growth restriction placentas. J Histochem Cytochem. 2018; 66(9): 617-630. http://doi: 10.1369/002215541 8772574 .

5. Orrù S, Nigro E, Mandola A, Alfieri A, Buono P, Daniele A, et al. A functional interplay between IGF-1 and adiponectin. Int J MolSci.2017;18(10):2145.http://doi: 10.3390/ijms18102145

6. Löfqvist C, Hellgren G, Niklasson A, Engström E, Ley D, Hansen-Pupp I; WINROP Consortium. Low postnatal serum IGF-1 levels are associated with bronchopulmonary dysplasia (BPD). Acta Paediatr. 2012;101(12):1211-6. http://doi: 10.1111/j.1651-2227.2012.02826.x

7. Liegl R, Löfqvist C, Hellström A, Smith LE. IGF-1 in retinopathy of prematurity, a CNS neurovascular disease. Early Hum Dev. 2016;102:13-9. http.//doi: 10.1016/j.earlhumdev.2016.09.008.

8. Hellström A, Ley D, Hansen-Pupp I, Hallberg B, Löfqvist C, van Marter L, et al. Insulin-like growth factor 1 has multisystem effects on foetal and preterm infant development. Acta Paediatr. 2016;105(6):576-86. http://doi: 10.1111/apa.13350.

9. Hellstrom A, Ley D, Hallberg B, Lofqvist C, Hansen-Pupp I, Ramenghi LA, et al. IGF-1 as a drug for preterm infants: a step-wise clinical development. Curr Pharm Des. 2017;23(38): 5964-70. http://doi: 10.2174/1381612823666171002114545

10. Agrogiannis GD, Sifakis S, Patsouris ES, Konstantinidou AE. Insulin-like growth factors in embryonic and fetal growth and skeletal development. Mol Med Rep. 2014;10(2):579-84. http: //doi: 10.3892/mmr.2014.2258

11. Yakar S, Isaksson O. Regulation of skeletal growth and mineral acquisition by the GH/IGF-1 axis: lessons from mouse models. Growth Horm IGF Res. 2016;28:26-42. http://doi: 10.1016/j. ghir.2015.09.004

12. Ley D, Hansen-Pupp I, Niklasson A, Domellof M, Friberg LE, Borg J, et al. Longitudinal infusion of a complex of insulin-like growth factor- 1 and IGF-binding protein-3 in five preterm infants: pharmacokinetics and short-term safety. Pediatr Res. 2013;73(1):68-74. http://doi: 10.1038/pr.2012.146

13. Dysinger M, Marusov G, Fraser S. Quantitative analysis of four protein biomarkers: an automated microfluidic cartridgebased method and its comparison to colorimetric ELISA.J Im- 
munol Methods. 2017;451:1-10. http://doi: 10.1016/j.jim. 2017.08.009

14. Average BW of male infants - RCPCH UK-WHO Neonatal and Infant Close Monitoring Growth Chart 2009. Available at: https://www.rcpch.ac.uk/sites/default/files/Boys_neonatal_ and_infant_close_monitoring_growth_chart.pdf

15. Average BW of female infants - RCPCH UK-WHO Neonatal and Infant Close Monitoring Growth Chart 2009. Available at: https://www.rcpch.ac.uk/sites/default/files/Girls_neonatal_and_infant_close_monitoring_growth_chart.pdf

16. Sharma D, Shastri S, Sharma P. Intrauterine growth restriction: antenatal and postnatal aspects. Clin Med Insights Pediatr. 2016;10:67-83. http://doi: 10.4137/CMPed.S40070

17. Sharma D, Farahbakhsh N, Shastri S, Sharma P. Intrauterine growth restriction - Part 2. J Matern Fetal Neonatal Med. 2016;29(24):3977-87. http://doi: 10.3109/14767058.2016.11 54525

18. Miller SL, Huppi PS, Mallard C. The consequences of fetal growth restriction on brain structure and neurodevelopmental outcome. J Physiol. 2016;594(4):807-23. http://doi: 10.1113/ JP271402
19. Hellström A, Ley D, Hansen-Pupp I, Hallberg B, Löfqvist C, van Marter L, et al. Insulin-like growth factor 1 has multisystem effects on foetal and preterm infant development. Acta Paediatr. 2016;105(6):576-86. http://doi: 10.1111/apa.13350

20. Shen Y, Zhang J, Zhao Y, Yan Y, Liu Y, Cai J. Diagnostic value of serum IGF-1 and IGFBP-3 in growth hormone deficiency: a systematic review with meta-analysis. Eur J Pediatr. 2015; 174(4):419-27. http://doi: 10.1007/s00431-014-2406-3

21. Chipman A, Morrison E. The impact of sex ratio and economic status on local birth rates. Biol Lett. 2013;9(2):20130027. http://doi: 10.1098/rsbl.2013.0027

22. Perng W, Rifas-Shiman SL, McCulloch S, Chatzi L, Mantzoros C, Hivert MF, et al. Associations of cord blood metabolites with perinatal characteristics, newborn anthropometry, and cord blood hormones in project VIVA. Metabolism. 2017;76: 11-22. http://doi: 10.1016/j.metabol.2017.07.001

23. de Jong M, Cranendonk A, Twisk JW, van Weissenbruch MM. IGF-1 and relation to growth in infancy and early childhood in very-low-birth-weight infants and term born infants. PLoS One. 2017;12(2):e0171650. http://doi: 10.1371/journal.pone. 0171650

Sažetak

\title{
POVEZANOST INZULINU SLIČNOG FAKTORA RASTA TIP 1 I INTRAUTERINOG RASTA
}

\author{
L. Banjac, J. Kotur-Stevuljevic, T. Gojkovic, V. Bokan-Mirkovic, G. Banjac i G. Banjac
}

Inzulinu sličan faktor rasta (IGF-1) je jedan od čimbenika koji utječu na intrauterini rast. Serumske razine IGF-1 su smanjene u fetusima s intrauterinim zastojem rasta. Cilj našega istraživanja bio je ispitati odnos između razine IGF-1 u nedonoščadi i intrauterinog rasta izraženog kao porođajna težina $(\mathrm{PT})$. Istraživanje je provedeno kao presječna studija. U studiju je bilo uključeno 71 nedonošče gestacijske dobi (GD) $\leq 33$ tjedna. Kvantitativno određivanje IGF-1 provedeno je u 33. postmenstruacijskom tjednu (pmt) radi bolje usporedivosti rezultata. Za kvantitativno određivanje IGF-1 rabili smo enzimski imunosorbentni test. Naši rezultati pokazali su da je srednja razina IGF-1 u nedonoščadi u 33. pmt iznosila $23,1 \pm 4,56$ (raspon 15,44-39,75) $\mu \mathrm{g} / \mathrm{L}$. Nije bilo razlike u vrijednostima IGF-1 između muške $(23,1 \pm 4,98 \mu \mathrm{g} / \mathrm{L}$ ) i ženske $(23,1 \pm 4,87 \mu \mathrm{g} / \mathrm{L})$ nedonoščadi. Također nije bilo značajne razlike u srednjim razinama IGF-1 između nedonoščadi s PT $<50$. i PT >50. percentila za GD ( $>0,50)$. Nedonoščad s niskom PT (<33. percentila) imala su statistički značajno nižu razinu IGF-1. Na temelju naših rezultata može se zaključiti da serumska razina IGF-1 odražava intrauterini rast samo u nedonoščadi male PT (<33. percentila), što bi mogao biti koristan podatak za buduću uporabu IGF-1 u terapijske svrhe.

Ključne riječi: Novorođenče; Inzulinu sličan faktor rasta I; Fetusni rast, retardacija; Presječna istraživanja 